\title{
Creative Ecology: Restoration of Native Forests by Native Trees
}

\author{
Akira Miyawaki \\ Japanese Center for International Studies in Ecology (JISE) and Nagano Nature Conservation Research Institute (NACRI), Japan \\ (Correspondence; Fax, 81-45-651-7692; E-mail,
}

Ecological devastation is becoming a serious problem locally to globally, inproportion as people seek affluent living circumstances. Environmental devastation originated mainly from nature exploitation and construction of cities and industrial institutions with non-biological materials. Humans have ignored the rules of nature, biodiversity and coexistence.

One of the best measures we can take anywhere, in order to restore ecosystems indigenous to each region and to maintain global environments, including disaster prevention and $\mathrm{CO}_{2}$ absorption, is to restore native, multi-stratal forests following an ecological method.

I would like to refer to the experimental reforestation projects based on ecological studies and their results at about 550 locations throughout Japan and in Southeast Asia, South America, and China. We have proved that it is possible to restore quasi-natural multi-stratal forest ecosystems in 20 to 30 years if we take the ecological method.

\section{Introduction}

Until recently there were two kinds of tree planting. One involves monocultures of needle-leaved trees or fastgrowing exotic species for the purpose of producing lumber. Of course producing lumber is an important business, but monocultures of species unsuited to the habitat, soil and climate will need maintenance, such as weeding and cutting off lower branches, for at least 20 years. Those conifers and exotic species are generally shallow-rooted and highly vulnerable to strong winds, heavy rain and dry air [1]. What is worse, many pine woods throughout Japan are damaged by forest fires and so called pine worms, and cedars (Cryptomeria japonica) cause pollen allergies which many people are suffering from every spring [2].

The other kind of planting is tree planting for beautification. Some examples of this are Japanese gardens, miniature gardens, and bon-sai, dwarf trees, which can be said to be enhanced to the most typical Japanese culture. In the Edo era, the Emperor's domains were covered with fine nearly-natural forests, and common people who envied them began to imitate and enjoy nature in and around their own small houses. They were apparently beautiful but cost a lot for maintenance. Recently decorative treeand flower-planting campaigns are popular in towns and cities [3]. We see many parks dotted with adult trees planted on the lawn. These plantings may be good to delight citizens' eyes. They not only need a lot of maintenance, however, but also are insufficient to protect environments and prevent disasters [2].

It will be a third planting method based on ecological studies that is indispensable to restore green environments, to prevent disasters, and to sustain local to global environments [4-6]. Through thorough vegetation-ecological field surveys, we grasp the potential natural vegetation of the area. Following the results of field surveys, we carry out what we call, restoration of "native forests by native trees" [7]. This reforestation is one of the most solid measures to restore environments of the earth locally to globally, with our gaze fixed upon the coming 21 st and 22nd centuries [8, 9].

The green surface of a multi-stratal forest of the potential natural vegetation is about thirty times as large as that of a mono-stratal lawn, which needs periodical maintenance. As for absorbing and accumulating $\mathrm{CO}_{2}$ multi-stratal native forests have a much larger capacity than do lawns.

When colonies, villages and towns were constructed in Japan, our ancestors usually grew forests indigenous to the region around shrines or temples, which are called Chinju-no-mori. Our method of reforestation "Native forests by native trees" is based on this traditional Japanese "Chinju-no-mori" and ecology, a new synthetic science that integrates biocoenoses and environment $[1,2]$.

In the $1960 \mathrm{~s}$ we started determination and systematization of phytosociological community units through steady ecological field investigations throughout Japan. Then we made maps of the actual vegetation of Japan, which can be used as diagnoses of natural environments, and middle-scaled $(1 / 500,000)$ potential natural vegetation maps of Japan, which can be used as ecological scenerios for restoration of green environments [10].

We choose the main tree species and their companion species from the potential natural vegetation of the area, collect acorns of those species, grow the seedlings in pots until the root system fully develops, and mix and plant them closely together following the system of natural forests. This is the way we succeeded in restoring forests at about 550 locations in Japan.

We applied this ecological method to reforestation in Malaysia in Southeast Asia, in Brazil and Chile in South America, and in some parts of China, and found each of them successful. We believe that to continue carrying out reforestation projects based on ecology on a global scale must be essential for our future wholesome environments. 


\section{Method}

The tree species must be chosen from the forest communities of the region in order to restore multi-stratal natural or quasi-natural forests. If the main tree species are badly chosen, it will be difficult to regenerate native forests which develop as time goes by. In the plant communities, if the top is authentic, the followers are also real, just like in human society.

For the proper choice of species, we first make a through field vegetation investigation of the area, especially in shrine and temple forests, old house forests, natural forests remaining on slopes, and substitute vegetation changed by various human impacts. The results of the investigations obtained in this way are called relevés, which are equivalent to a census of green enviornments [3, $4,11]$.

Next, we decide local community units by tablework comparing relevés and grouping similar species combinations. Then we compare them with community units investigated and systematized in other parts of the world and see the species combinations. When we see species combinations, we find high-fidelity species for particular communities. These species are called character species. We decide phytosociological units based on the character species. We compare phytosociological units widely from natural forests to secondary communities, and decide "associations”, basic units of a plant community system, which can be applied to worldwide vegetation science. Likewise, we group the units into alliances, orders and classes by species combinations. In this way the hierarchical vegetation community system is decided [7].

Vegetation maps are drawn so that even non-experts in vegetation can understand the vegetation community units and their distribution. The present distributions of vegetation communities are drawn onto actual vegetation maps, which work as vegetation-ecological diagnoses not only for pure scientific purposes but also for the purpose of new utilization of land and decisions whether reforestation is needed [12].

There is another concept of vegetation, i.e. the potential natural vegetation [13]. Without any human impact, what vegetation could the land hold as the sum total of natural environments? The potential natural vegetation indicates the potential capacity of the land, theoretically considered, as to what vegetation it can sustain. To decide the potential natural vegetation, we investigate remaining natural vegetation and compare it with various secondary vegetation types from the factors of time and space. We also investigate the soil profile, topography and land utilization and put these together to grasp the potential natural vegetation [14].

Potential natural vegetation maps are essential for each ecological study field and are significant as ecological diagnoses for restoration of green environments. We found it possible to restore native green environments, multi-stratal forests, by choosing the main species from the potential natural vegetation of the area and planting them mixed and densely with as many companion species as possible [8].
The main tree species from the potential natural vegetation are generally deep- and straight-rooted and have been said to be difficult to transplant. We solved the problem by planting potted seedlings. We first collect seeds, that is, acorns. We germinate the seeds, move the seedlings to pots when two or three leaves have sprouted, and cultivate them until the root groups fill the containers and seedlings grow 30 to 50 centimeters high. It takes one-and-a-half years to two years in the temperate climate zone where most cities of Japan and the United States are located. In the tropical rain forest zone, where Borneo and Brazil lie, it takes only six to eight months to complete the growth of the potted seedlings [15].

Then we adjust the soil conditions of the planting site. Topsoil is usually washed away both in Japanese urban areas and on tropical barren land, from shifting cultivation and forest felling. Therefore it is necesarry to recover 20 to 30 centimeter-deep topsoil by mixing the soil of the region and compost from organic materials such as fallen leaves, mowed grass and so on.

Next we plant potted seedlings of the main tree species from the potential natural vegetation along with companion species according to the system of natural forests. Dense and mixed planting of two or three seedlings per square meter will be appropriate.

Mulching with organic materials such as rice straw is needed in order to prevent soil erosion and moisture loss after planting. For two or three years after planting, we have to cut or pull weeds and utilize them as mulching material by leaving them around the young trees. In about three years the trees grow 2 to 3 meters high, and the crown covering the forest floor comes to keep the sunlight from coming in. Consequently very few weeds can grow. This is how nature manages itself through natural selection. Three years after planting, the site basically becomes maintenance free.

Dense and mixed planting of community species of indegenous forests will need no watering, insecticides or herbicides, with some exceptions. Natural management is the best management [7].

\section{Experiments and Results}

\subsection{Internal reforestation}

Since 1973 we have been forming environment protection forests around newly built ironworks and power stations in cooperation with farsighted Japanese corporations such as Nippon Steel Corp., Tokyo Electric Power Co., Kansai Electric Power Co., Honda Engineering Co., Toray Textile Co., Mitsui Estate Co., Mitsubishi Corp., JUSCO EAON Group, and so on. In the latter half of the 1970s municipalities like Kanagawa Pref., Okayama Pref., Nagano Pref., Nara Pref., Yokohama City, Mikawa City, and Nagoya City, as well as the central government including the Ministry of Construction, began to ask us to regenerate native forests with native trees. The planting sites range $3,000 \mathrm{kms}$ from Hokkaido in the north to Okinawa in the south. As of August 1998, we have restored native forests at about 550 locations, each of which is successful (Fig. 2, Color plates 1, 2, 5 8). 


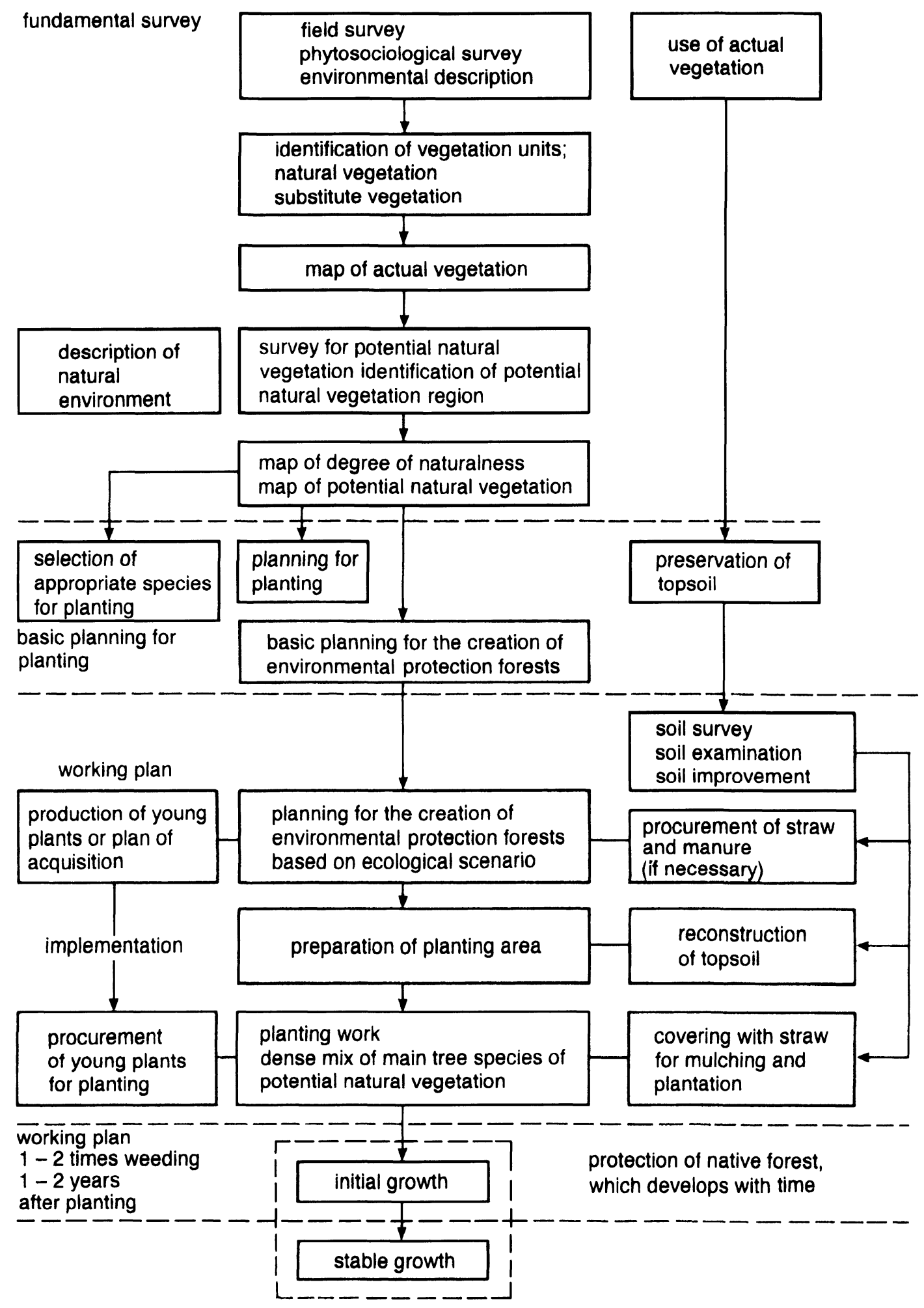

Fig. 1 Flow chart for the restoration and creation of native forests [12].

Why is it indispensable to plant trees in so many places around the infrastructure? To this question the Great Hanshin Earthquake on January 17, 1995, gave us a definite answer.

We made field investigations right after the earthquake. Structures built of iron and cement, including modern buildings and some parts of elevated highways and Shinkansen railways, were destroyed easily, and some of them burst into flames. They had cost tens of billions of yen and involved the latest techniques. We believed they were the strongest structures, but non-biological materials showed weakness against such disasters, which hit us once in some hundred years (Color plate 3).

On the other hand, not a tree of the main component 


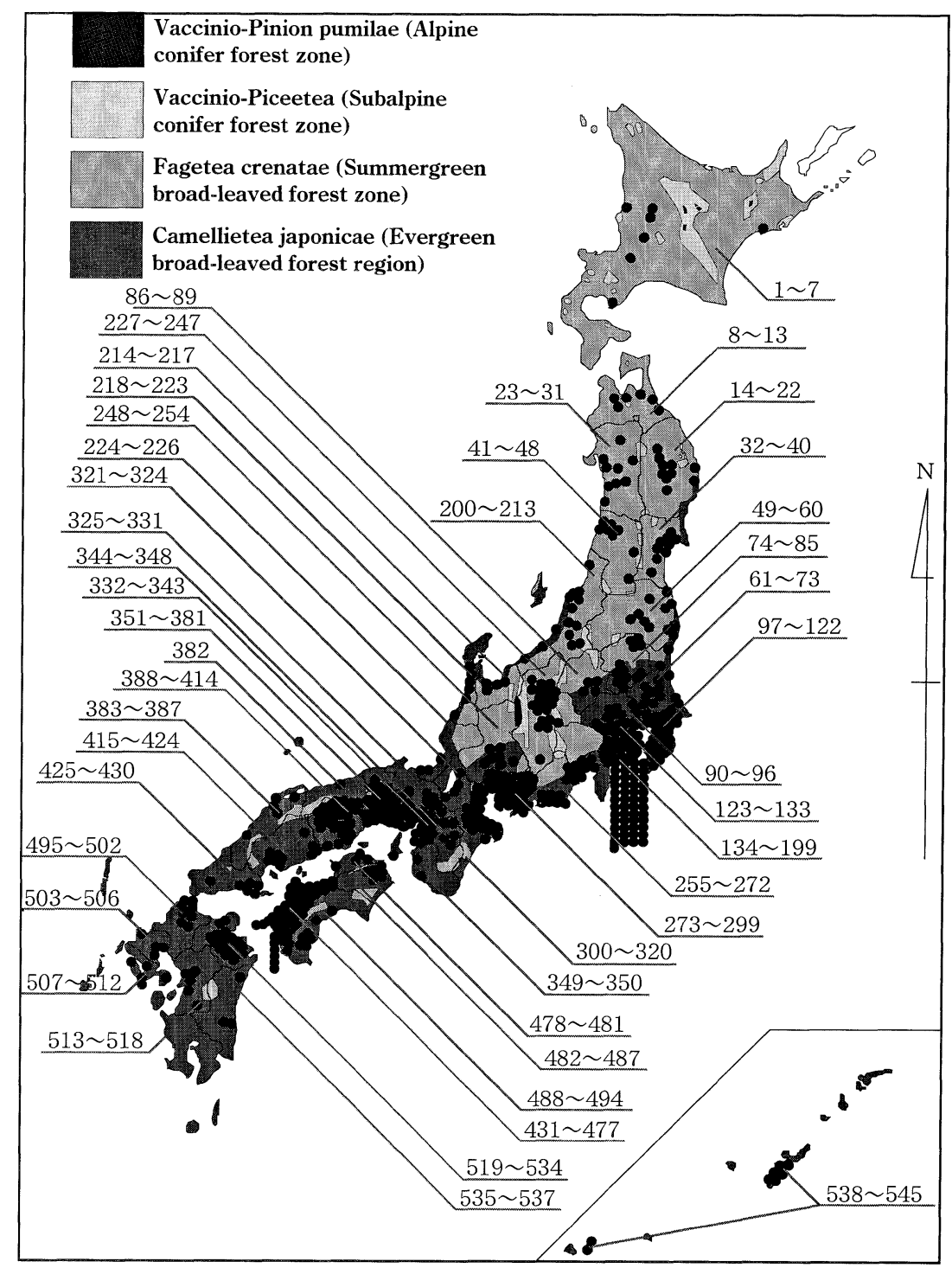

Fig. 2 Planting locations of native forests by native trees based on the vegetation ecological scenario as of Oct. 1998. The numbers represent the planting locations. (place names omitted).

of the potential natural vegetation fell. Where evergreen broad-leaved trees from laurel forests were planted in a line, fire was stopped. They proved to have a fire prevention function in many places (Color plate 4).

In the earthquake many houses were destroyed and levelled to the ground. Many of the nearly 6,000 victims were crushed to death under their houses. Some houses had evergreen trees aound them in spite of their shade and falling leaves. These trees stopped the falling roofs and pillars, and made openings in the rubble. The people living

Photo 1 Ecological planting around Gobo thermal power plant of Kansai Electric Power Co. on a manmade island in the Pacific Ocean (July, 1983).

Photo 2 Same place after 12 years (December, 1995). The trees have now grown much higher.

Photo 3 Disastrous earthquake hit Hanshin District (January 17, 1995).

Photo 4 A fire was stopped by a line of evergreen Oak trees (Quercus glauca), main species from the potential nautral vegetation.

Photo 5 Planting along Shin-shonan Bypass by primary school students.

Photo 61,200 primary school children planting seedlings along the Kashihara Bypass (March, 1982).

Photo 7 Same place after 14 years (July, 1996).

Photo 8 20,000 seedlings planted by 2,000 people around the Shirakawa Dam, Nara Prefecture. Prof. H. Sano (right) and Madame Elisabeth Sano (center), participating in the planting festival (author left) (April, 1996).

Photo 9 The first planting festival at the site in Bintulu, Sarawak, Malaysia. 6,000 seedlings planted by 2000 people (July 15, 1991).

Photo 10 Same place after 4 years (January 16, 1995). At present the trees have grown higher.

Photo 11 The first planting festival to regenerate tropical lowland forests near Belém, Brazilian Amazon (May 18, 1992).

Photo 12 Same place after 4 years.

Photo 13 Planting 14 species of seedlings from native tree species including Nothofagus trees in Concepción, Chile (May 26, 1992).

Photo 14 Same place after 4 years (February 2, 1996). 

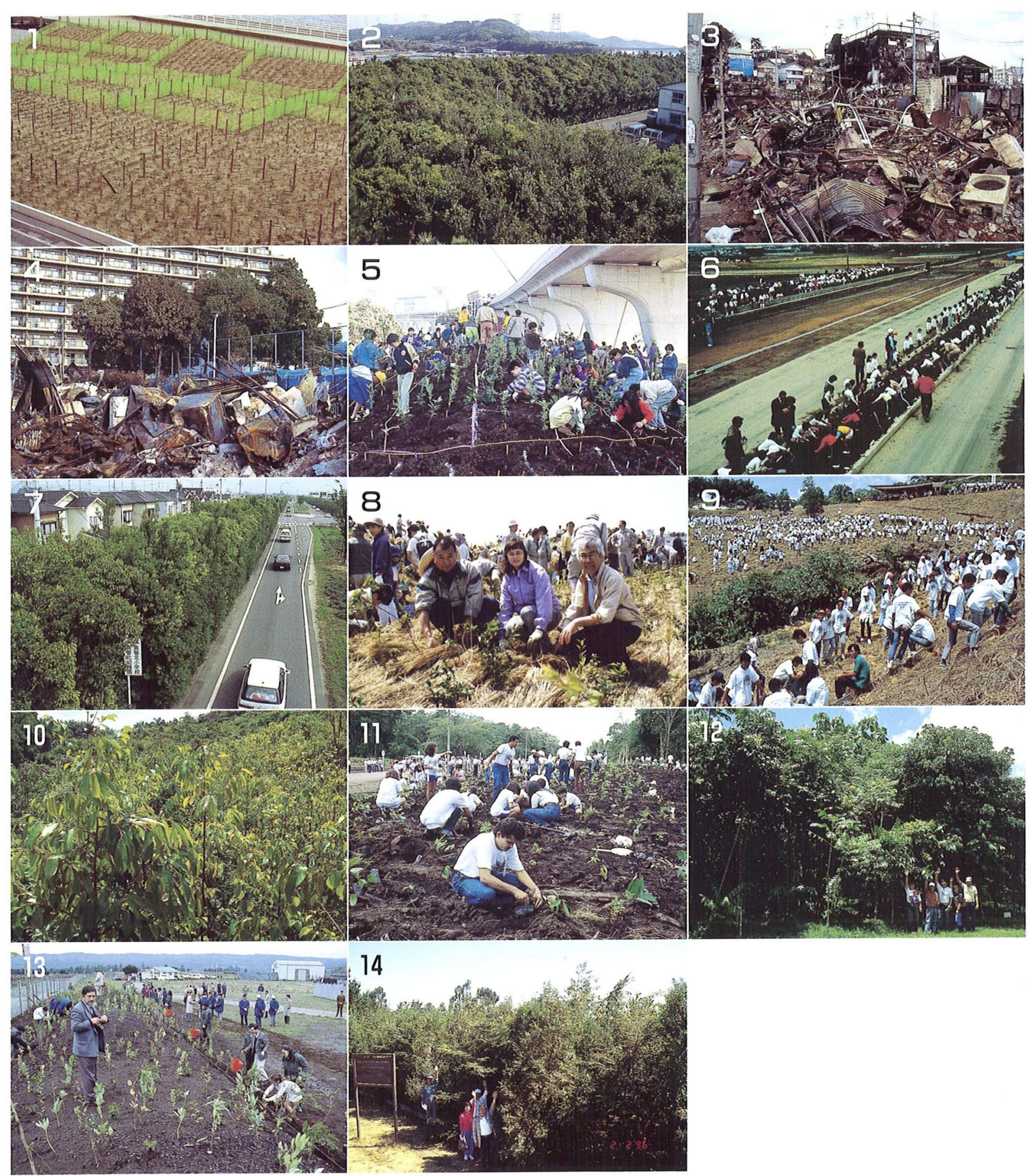
there could probably escape from the dread of death through the openings.

Lately the Ministry of Construction is beginning to plant seedlings from the potential natural vegetation along expressways, under the so-called Miyawaki Method based on the ecological scenario (Color plate 5). School children led by their teachers plant seedlings as a part of the regular curriculum [1].

If these programs had started in Kobe ten years before the earthquake, the planted seedlings would have grown to form a forest belt about $10 \mathrm{~m}$ high. Then the drivers might not have lost their lives when the expressway was destroyed, through softer landing on the forest.

This is another example of reforestation along the expressway. In Nara Prefecture construction of the Kashihara Bypass met with opposition of the inhabitants and was suspended for ten years. Some adovocated a greenery campaign to plant seedlings along the expressway as a way out. On March 13, 1982, school children planted seedlings following the ecological method (Color plate 6). Sixteen years have passed since then. Many of those children graduated from school and got married during the period. When they come back to their home town, they proudly see the forest belt (Color plate 7). When their own children become primary school students, they will surely take them to the forest and say, "The seedlings I planted with my hands when I was as old as you are now have grown to this great forest."

The staff in the civil engineering bureau in Nara Prefectural Government knew the case of Kashihara Bypass and held a planting festival around Ohta Dam. 2,000 people, including the Governor of Nara Prefecture, planted 20,000 seedlings from the potential natural vegetation. Prof. Sano and his wife as well as many students of Nara Institute of Science and Technology took part in the festival and planted with sweat on their brows (Color plate 8). I would like people in Nara Prefecture to keep watching the growth of the seedlings with a scientific eye and love towards life.

\subsection{Restoration of tropical rain forests in Southeast Asia}

In 1978 we began vegetation field investigations in Indonesia (Borneo), Thailand, and Malaysia, from mangrove forests along the seacoast to tropical rainforests, tropical dry forests and laurel forests in the mountains in Thailand [16, 17]. Based on the results of the investigations, we began a joint restoration project with Mitsubishi Corp. and the University of Agriculture, Malaysia in 1990. The planting site was 800 ha of barren land on the Bintulu campus of the university, Sarawak State (northeast Borneo) $[15]$.

Restoration of tropical rainforests has been considered to be quite difficult, and it was usual to plant rapid-growing speices such as Eucalyptus from Australia, and long-leaf pine, Pinus taeder from America, and Acacia mangium. These exotic rapid-growing species grow very fast at the beginning. Since they grow in a monostratum, however, they are highly vulnerable to dry air, strong wind and insect damage. Reforestation with these species is not always successful.

We chose the main tree species from the potential natural vegetation of the area, Dipterocarpaceae, including Hopea, Shorea, and Dipterocarpus. We also planted as many companion species of the tropical rainforest communities as possible, in order to follow the natural biodiversity. This may be the newest method of reforestation in the world. We have planted 91 species from the potential natural vegetation in all (Table 1) [18].

I would like to show the case of Plot 203 of the Bintulu reforestation as one example. There we had a lot of difficulty in the first stage of growth.

On July 15, 1991, we and 2,000 participants dug 6,000 small holes with our hands and planted 6,000 seedling. The record of their growth is represented in Fig. 3 and Color plates 9 and 10. The survival rates of the individuals and the groups in six years are shown in Fig. 4. During the first few years tenacious grass weeds came out and we cut them and covered the forest floor with them for supplementary mulching. After three years the plantation basically required no maintenace. It is six years since the planting, and the trees have grown steadily to reach $6 \mathrm{~m}$ to $10 \mathrm{~m}$ high. Every year after the first planting 30-80 volunteers from Japan and people from Malaysia participate in the planting festival in Bintulu. Until now 330,000 seedlings have been planted on 50 ha of land. We can see them developing into quasi-natural forests [19].

Adopting the same method, we have succeeded in restoring disaster-preventing, environment-protecting forests around newly built shopping centers backed by JUSCO in Kuala Lumpur, Melaka, Ippo (Malaysia), and Bangkok (Thailand). The forests restored in urban and peri-urban areas are highly valued by local people.

The royal family of Thailand had a lot of interest in ecological reforestation, and we started planting dry Dipterocarpus and other species from the potential natural vegetation along the boundary between western Thailand and Myanmar. We named the joint work the Royal Princess Sirindhorn Project.

\subsection{Examples in South America}

In December 1990 we started an experimental regeneration project for lowland tropical forests in collaboration with Pará Agricultural University in Belém, northern Brazil. We collected 92 species mostly from the potential natural vegetation, including the main species Virola, and made potted seedlings with fully developed root systems. This project was backed by EIDAI do Brazil Madeiras S.A. and Mitsubishi Corp. The first planting festival was held on May 18, 1992, attended by the Mayor of Belém, Mr. and Mrs. Murazumi, Japanese Ambassador extraodinary and plenipotentiary to Brazil, President of Pará Agricultural University, and many other people (Color plate 11). After that every year we continually plant seedlings at planting festivals. They grow steadily and some individuals reach $10 \mathrm{~m}$ to $15 \mathrm{~m}$ high in five years (Color plate 12).

At this site we made haste in planting and intentionally mixed indegenous species and rapid-growing pioneer species. Rapid-growing species, including Barsa, grew very 
Table 1 The species list of planted trees for reforestation in Malaysia

\begin{tabular}{|c|c|c|c|}
\hline No. & Species Name & Family Name & Local Name \\
\hline 1 & Shorea atrinervosa & Dipterocarpaceae & Selangan batu hitam \\
\hline 2 & Shorea balanocarpoides & Dipterocarpaceae & Meranti lun \\
\hline 3 & Shorea beccariana & Dipterocarpaceae & Meranti langgai \\
\hline 4 & Shorea brunnescens & Dipterocarpaceae & Selangan batu tinteng \\
\hline 5 & Shorea crassa & Dipterocarpaceae & Selangan batu daun tebal \\
\hline 6 & Shorea dasyphylla & Dipterocarpaceae & Meranti batu \\
\hline 7 & Shorea domatiosa & Dipterocarpaceae & Selangan batu lubang idon \\
\hline 8 & Shorea gibbosa & Dipterocarpaceae & Meranti lun gajah \\
\hline 9 & Shorea glaucescens & Dipterocarpaceae & Selangan batu daun nips \\
\hline 10 & Shorea laxa & Dipterocarpaceae & Lun timbul \\
\hline 11 & Shorea leprosula & Dipterocarpaceae & Meranti tembaga \\
\hline 12 & Shorea macrophylla & Dipterocarpaceae & Engkabang jantung \\
\hline 13 & Shorea macroptera & Dipterocarpaceae & Meranti melantai \\
\hline 14 & Shorea maxwelliana & Dipterocarpaceae & Kumus hitam \\
\hline 15 & Shorea mecistopteryx & Dipterocarpaceae & Meranti kawang burung \\
\hline 16 & Shorea multiflora & Dipterocarpaceae & Lun jantan \\
\hline 17 & Shorea ovata & Dipterocarpaceae & Meranti pitis \\
\hline 18 & Shorea parvifolia & Dipterocarpaceae & Meranti sarang punai \\
\hline 19 & Shorea pauciflora & Dipterocarpaceae & Nemesu \\
\hline 20 & Shorea rubella & Dipterocarpaceae & Meranti laut putih \\
\hline 21 & Shorea scaberrima & Dipterocarpaceae & Meranti paya bersisik \\
\hline 22 & Shorea scabrida & Dipterocarpaceae & Meranti lop \\
\hline 23 & Shorea venulosa & Dipterocarpaceae & Meranti tangkai panjang pa \\
\hline 24 & Hopea beccariana & Dipterocarpaceae & Merawan/Chengal pasir \\
\hline 25 & Hopea bracteata & Dipterocarpaceae & Luis \\
\hline 26 & Hopea kerangasensis & Dipterocarpaceae & Luis kerengas \\
\hline 27 & Hopea pentanervia & Dipterocarpaceae & Chengal paya \\
\hline 28 & Parashorea parvifolia & Dipterocarpaceae & Urat mata bukit \\
\hline 29 & Parashorea smythiesii & Dipterocarpaceae & Urat mata daun puteh \\
\hline 30 & Dryobalanops aromatica & Dipterocarpaceae & Kapur peringgi \\
\hline 31 & Dryobalanops beccarii & Dipterocarpaceae & Kapur Bukit \\
\hline 32 & Dipterocarpus rigidus & Dipterocarpaceae & Keruing utap \\
\hline 33 & Dipterocarpus stellatus & Dipterocarpaceae & Keruing \\
\hline 34 & Cotylelobium burckii & Dipterocarpaceae & Resak durian \\
\hline 35 & Cotylelobium malayanum & Dipterocarpaceae & Resak batu \\
\hline 36 & Cotylelobium melanoxylon & Dipterocarpaceae & Resak hitam \\
\hline 37 & Upuna borneensis & Dipterocarpaceae & Upun \\
\hline 38 & Vatica cuspidata & Dipterocarpaceae & Resak \\
\hline 39 & Vatica mangachapoi & Dipterocarpaceae & Resak \\
\hline 40 & Vatica nitens & Dipterocarpaceae & Resak daun panjang \\
\hline 41 & Vatica venulosa & Dipterocarpaceae & Resak \\
\hline 42 & Dracontomelon dao & Anacardiaceae & Sengkuang \\
\hline 43 & Gluta wallichii & Anacardiaceae & Rengas \\
\hline 44 & Mangifera pajang & Anacardiaceae & Embang \\
\hline 45 & Parishia insignis & Anacardiaceae & Upi bung \\
\hline 46 & Parishia maingayi & Anacardiaceae & Upi paya \\
\hline 47 & Pentaspadon motleyi & Anacardiaceae & Pelajau \\
\hline 48 & Neouvaria acuminatissima & Annonaceae & Karai \\
\hline 49 & Alstonia angustifolia & Apocynaceae & Pelai \\
\hline 50 & Alstonia angustiloba & Apocynaceae & Pelai \\
\hline 51 & Alstonia scholaris & Apocynaceae & Pelai lilin \\
\hline 52 & Durio carinatus & Bombacaceae & Durian burong \\
\hline 53 & Durio zibethinus & Bombacaceae & Durian \\
\hline
\end{tabular}


Table 1 (continued)

\begin{tabular}{|c|c|c|c|}
\hline No. & Species Name & Family Name & Local Name \\
\hline 54 & Dacryodes costata & Burseraceae & Kedondong \\
\hline 55 & Santiria megaphylla & Burseraceae & Seladah \\
\hline 56 & Diospyros sarawakana & Ebenaceae & Kaya malam \\
\hline 57 & Baccaurea angulata & Euphorbiaceae & Ocong \\
\hline 58 & Baccaurea bracteata & Euphorbiaceae & Tampoi paya \\
\hline 59 & Baccaurea lanceolata & Euphorbiaceae & Tapus/Empaon(u)g \\
\hline 60 & Elateriospermum tapos & Euphorbiaceae & Kelampai/Perah \\
\hline 61 & Calophyllum ferrugineum & Guttiferae & Bintangor \\
\hline 62 & Calophyllum macropodum & Guttiferae & Bintangor daun besar \\
\hline 63 & Calophyllum nodosum & Guttiferae & Bintangor daun halus \\
\hline 64 & Calophyllum sclerophyllum & Guttiferae & Bintangor jangkar \\
\hline 65 & Garcinia cuspidata & Guttiferae & Knadis daun kechil \\
\hline 66 & Stemonurus scorpioides & lcacinaceae & Semburuk \\
\hline 67 & Eusideroxylon zwagerri & Lauraceae & Belian \\
\hline 68 & Litsea $\mathrm{sp}$ & Lauraceae & Medang \\
\hline 69 & Barringtonia sp. & Lecythidaceae & Putat \\
\hline 70 & Archidendron ellipticum & Leguminosae & Petai belalang/kedaung \\
\hline 71 & Dialium sp. & Leguminosae & Keranji \\
\hline 72 & Koompasia malaccensis & Leguminosae & Kampas \\
\hline 73 & Sandoricum koetjape & Meliaceae & Kelampuk \\
\hline 74 & Artocarpus integer & Moraceae & Cempedak \\
\hline 75 & Artocarpus rigidus & Moraceae & Terap \\
\hline 76 & Parartocarpus venunosus & Moraceae & Minggi \\
\hline 77 & Engenia castanea & Myrtaceae & Ubah \\
\hline 78 & Engenia chrysantha & Myrtaceae & Ubah \\
\hline 79 & Engenia grandis & Myrtaceae & Ubah jambu \\
\hline 80 & Engenia hoseana & Myrtaceae & Ubah \\
\hline 81 & Engenia lineata & Myrtaceae & Ubah daun kecil \\
\hline 82 & Engenia ochnecarpa & Myrtaceae & Ubah parit \\
\hline 83 & Tristania beccarii & Myrtaceae & Selunsur \\
\hline 84 & Whiteodendron mountonianum & Myrtaceae & Kawi \\
\hline 85 & Sarcotheca glauca & Oxalidaceae & Tulang payong \\
\hline 86 & Pometia pinnata & Sapindaceae & Kasai/Selan \\
\hline 87 & Ganua pierrei & Sapotaceae & Ketiau putih \\
\hline 88 & Palaquium gutta & Sapotaceae & Nyatoh riau \\
\hline 89 & Scaphium macropodum & Sapotaceae & Kembang semangkuk \\
\hline 90 & Eurycoma longifolia & Simaroubaceae & Tongkat ali \\
\hline 91 & Gonystylus maingayi & Thymelaeaceae & Ramin batu air \\
\hline
\end{tabular}

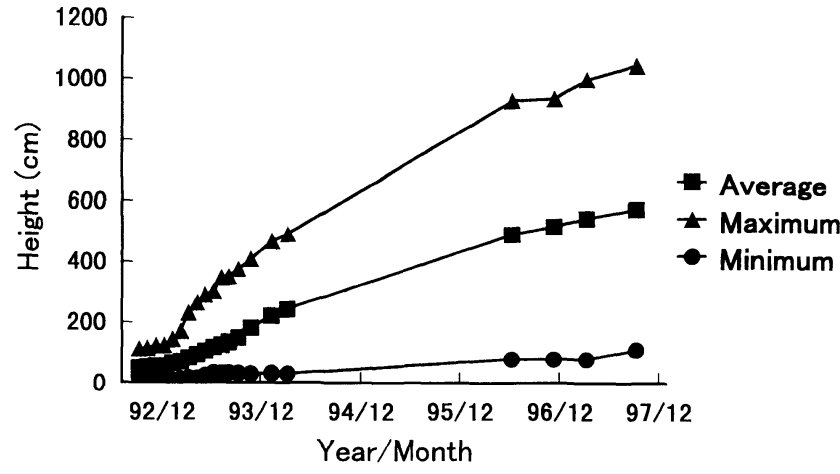

Fig. 3 Growth curve in height on PQ 203 in Bintulu, Sarawak, Malaysia.

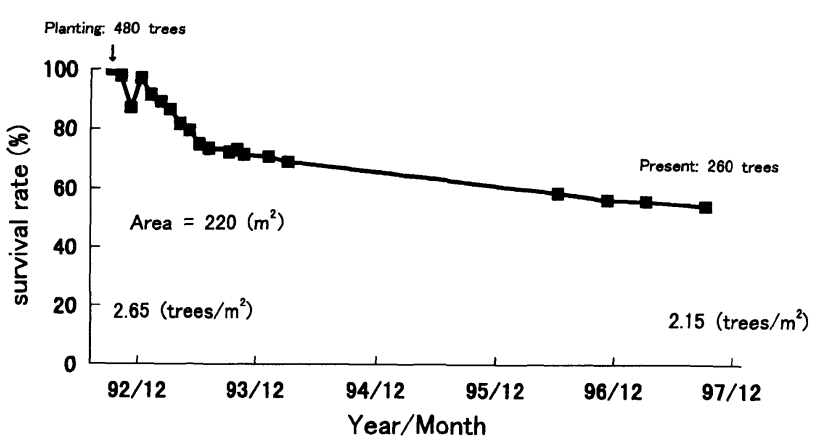

Fig. 4 Survival rate with passage time on PQ 203 in Bintulu, Sarawak, Malaysia. 
fast, but because of their shallow root systems some of them fell in the strong wind and received some other damage. They also made shade over the indegenous species like Virola, which were growing more slowly. In conclusion it is the best and the most secure method to mix and plant spcecies from the potential natural vegetation following the system of natural forests, just as we did in Japan and Southeast Asia.

In Concepción, Chile, we practiced reforestation by mixed, dense planting of 14 species of Nothofagus. Though it was said to be difficult to restore native forests in the area because of dry air in summer and overgrazing, we have found that native forests can be restored if we take sufficient care for the first several years after planting (Color plates 13 and 14).

\subsection{Reforestation in China}

Forest devastation is quite serious around the Great Wall, the more than 2000-year-old structure stretching $2,600 \mathrm{~km}$, which is called the symbol of the civilization of Great China. Several projects have been tried but were not necessarily successful.

We began field investigations to understand the potential natural vegetation around the Great Wall, in cooperation with the People's Government of Beijing and AEON Environment Foundation of Japan. We collected $80,000-1,000,000$ acorns of indegenous species, including Quercus mongolica, and germinated them to grow seedlings in pots. On July 4, 1998, the first planting festival was held, with the help of 1,400 volunteers from Japan and about 1,200 volunteers from China. Chinese people took the trouble of digging $175,00060 \mathrm{~cm}^{3}$ holes in the

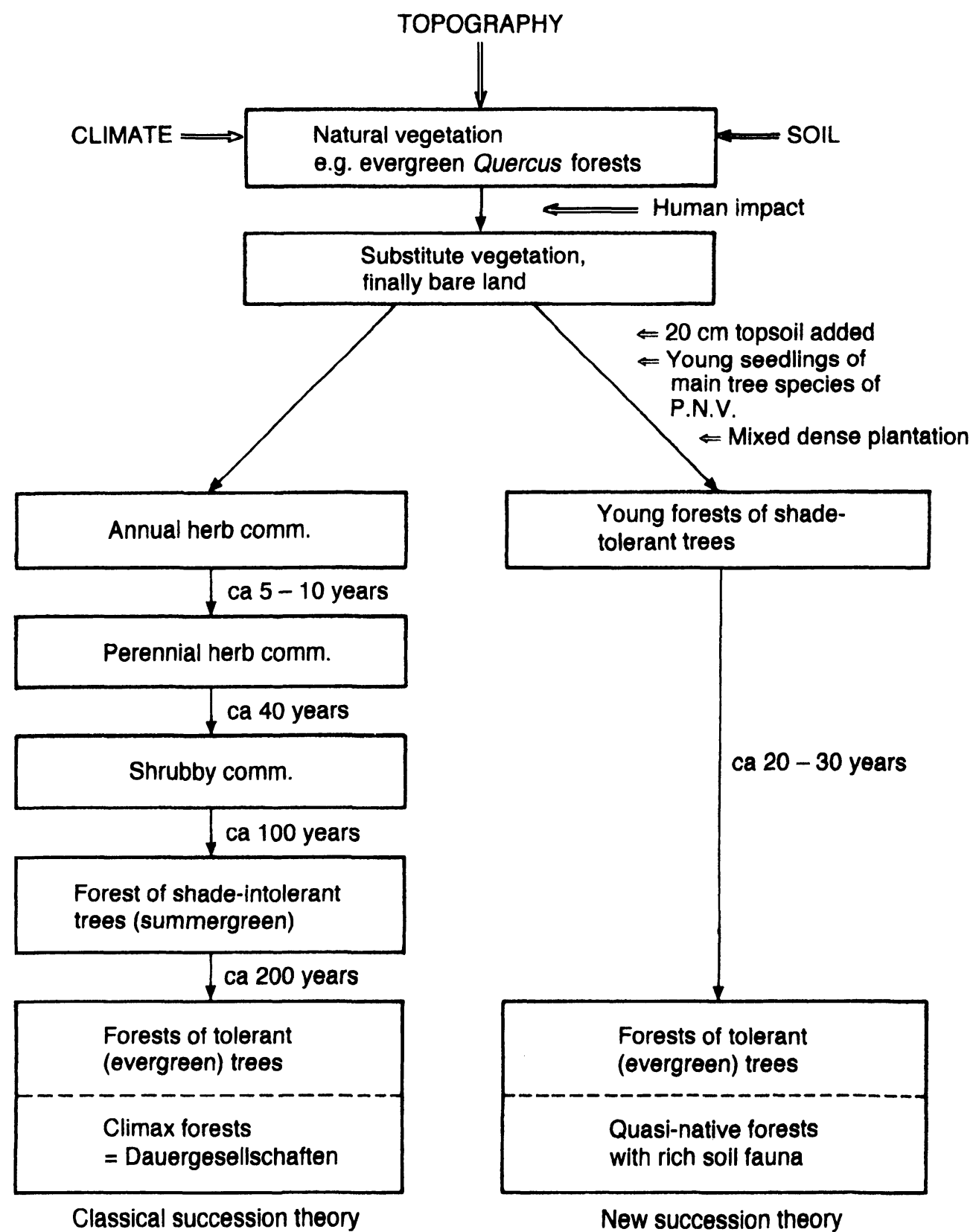

Fig. 5 Comparison between our new succession theory and classical theory (Laurel forest area in Japan) [14]. 


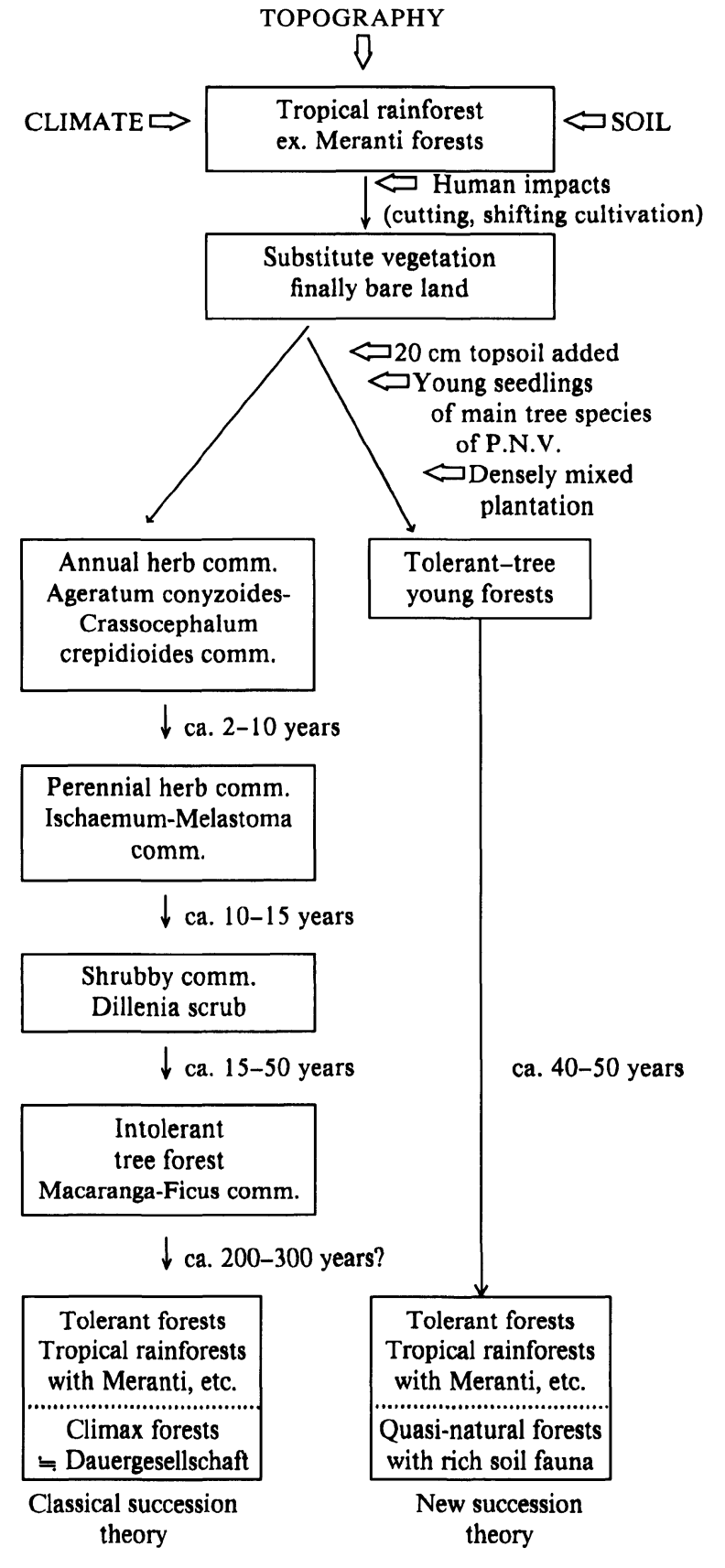

Fig. 6 Comparison between our new succession theory and classical theory (Case in Bintulu, Sarawak, Malaysia).

rocky surface with no topsoil, and we could plant seedlings with the view to an international green wall of native forests. This project is a three-year program, and 390,000 seedlings are planned to be planted in total.

\section{Discussion and Conclusion}

As Clements mentioned [20], annual plants on barren land are succeeded by perennial grass, sun shrubs, lightdemanding fast-growing trees, and finally indegenous natural forests. It was said that it would take 150-200 years in Japan to reach the final indegenous natural forests by secondary progressive succession and 300-500 years in Southeast Asia (Figs. 5 and 6).
Several hundred years for reforestation is too long for us, however, because we live in a world where industry and urbanization are developing very rapidly. We tried ecological reforestation by recovering topsoil and planting seedlings in pots with fully developed root systems directly from the terminal vegetation in succession, that is, the potential natural vegetation. It is proved here that multistratal quasi-natural forests can be built in 15-20 years in Japan and 40-50 years in Southeast Asia by ecological reforestation based on the system of natural forests. Among 550 locations of our planting throughout Japan we don't see a single failure. We succeeded in restoration of native forests from in cold-temperate zone to in tropical forest zone.

550 locations is far from enough when we consider the whole $380,000 \mathrm{~km}^{2}$ land of Japan, much more on a global scale. We all should set to restoration and recreation of global environments in every place in the world by the ecotechnological method. We can start at once, following the rules of biocoenoses. Farsighted top managers of administrations, corporations, and communities can be general directors. Scientists write ecological scenarios for environment restoration. Citizens are the main characters on the stage. All the people on the earth share the work in a sweat for the sound future of human beings.

Ecology was originally viewed as a science of discovery and played the role of critic when environmental pollution occurred in the 1970s. Now ecology should be creative in order to restore environments and build better living conditions. We expect all scientists in the world to see our results positively and to begin to help make new affluent circumstances for the future in their own area. We hope to struggle together for creative ecology.

\section{Acknowledgements}

I had learned the concept of the potential natural vegetation for two and a half years since 1958, from Prof. Reinhold Tüxen, the then Director of Bundesamstalt für Vegetationskartierung in then West Germany. After coming back to Japan I began vegetation field investigations with the knowhow in the 1970s when the Japanese economy rapidly grew. Since then many farsighted international and domestic corporations, Ministries including the Ministry of Education, governers and mayors of local public bodies, and so many citizens have been working with us. I would like to express my gratitude to every one of them.

\section{References}

[1] Miyawaki, A., Fujiwara, K., Ozawa, M., 1993. Bull. Inst. Environ. Sci. Technol. Yokohama Natl. Univ. 19: 73-107.

[2] Miyawaki, A., 1997. Green Environments and Vegetation Science Chinjuno-mori (native forests with native trees in shrines and temples) to World Forests. NTT Publisher, Tokyo, $239 \mathrm{pp}$.

[3] Miyawaki, A., 1982. Bull. Inst. Environ. Sci. Technol. Yokohama Natl. Univ., 11: 107-120.

[4] Miyawaki, A., 1975. Entwicklung der Unweltschutz-Pflanzungen und Ansaaten in Japan. In: Tüxen, R. (Ed.) Sukuzessionsforschung. Bericht über das Internationale 
Symposium der Internationalen Vereinigung für Vegetationskunde. Vaduz, Cramer, 237-254.

[5] Miyawaki, A., Fujiwara, K., Box, E.O., 1987. Bull. Inst. Environ. Sci. Tech., Yokohama Natl. Univ. 14: 67-82.

[6] Miyawaki, A., Golley, F.B., 1993. Forest reconstruction as ecological engineering. Ecological Engineering. Elsevier, Amsterdam, 2: 333-345.

[7] Miyawaki, A., 1989. Restoration of evergreen broad-leaved forest ('laurel forest') in Japan. In: Academy, Ch. (Ed.). The World Community in Post Industrial Society. The Human Encounter with Nature: Destruction and Reconstruction. Wooseok Publishing Co., Seoul, 5: 130-147.

[8] Miyawaki, A., 1998. Vegetation ecological study for restoration of forest ecosystems. Fujiwara, K. (Ed.), A vegetation ecological study for the restoration and rehabilitation of green environment based on the creation of environmental protection forests in Japanese Archipelago. Inst. Veget. Sci., Inst. Environ. Sci. Technol. Yokohama Natl. Univ., 267298.

[9] Miyawaki, A., 1998. Ecological Engineering. (in press).

[10] Miyawaki, A., et al., 1980-1988. Vegetation of Japan. vol. 1-10, 1. Yakushima 376 pp., 2. Kyushu 484 pp., 3. Shikoku 539 pp., 4. Chugoku 540 pp., 5. Kinki 596 pp., 6. Chubu 604 pp., 7. Kanto 641 pp., 8. Tohoku 605 pp., 9. Hokkaido 563 pp., 10. Okinawa and Ogasawara $676 \mathrm{pp}$. Each vol. with color vegetation maps and tables.

[11] Miyawaki, A., 1981. Energy policy and green environment on the base of ecology. In: Fazzolare, R.A., Smith, C.B. (Eds.), Beyond the Energy Crisis Opportunity and Challenge. Oxford and New York, 581-587.

[12] Miyawaki, A., 1996. Restoration of biodiversity in urban and peri-urban environments with native forests. In: di Castri, F., Younes, T. (Eds.). Biodiversity, Science and De- velopment, Towards a New Partnership. CAB International, 558-565. Printed and bound at the University Press, Cambridge, UK.

[13] Tüxen, R., 1956. Die heutige potentielle natürliche Vegetation als Gegenstand der Vegetationskartierung. Angew. Pflanzensoziologie 13: 5-42. Stolzenau/Weser.

[14] Miyawaki, A., 1992. Restoration of evergreen broad-leaved forests in the Pacific region. In: Wali, M.K. (Ed.), Ecosystem Rehabilitation, Ecosystem analysis and synthesis. SPB Academic Publishing, The Hague, Netherlands, 2: 233-245.

[15] Miyawaki, A., 1993. Restoration of native forests from Japan to Malaysia. In: Lieth, H., Lahmann, M. (Eds.), Restoration of Tropical Forest Ecosystems. Kluwer Academic Publishers, Netherlands, 5-24.

[16] Miyawaki, A., 1982. Phytosociological study of East Kalimantan, Indonesia. Bull. Inst. Environ. Sci. Technol. Yokohama Natl. Univ., 8: 219-232.

[17] Miyawaki, A., 1992. Ecological perspectives for sustainable development of Southeast Asian forests. Proceedings of International Seminar on Agricultural Change and Development in Southeast Asia (SACOESA-III), Tokyo Univ. of Agriculture, 97-106.

[18] Megro, S., Miyawaki, A., 1997. Tropical Ecology. 38: 237245.

[19] Miyawaki, A., Meguro, S., 1998. Restoraton of tropical rain forests in Sarawak, Malaysia. In: Sjögren, E., Maarel, E., Pokarzhevskaya, G., (Eds.), Studies in Plant Ecology, Vegetation science in retrospect and perspective, Uppsala, 20: p. 60 .

[20] Clements, F.E., 1916. Plant succession: An analysis of the development of vegetation. Carbegie Institution of Washington Publ., Washington, 242, 1-512. 